\title{
CLINICAL REVIEW OF THE GRITTI-STOKES AMPUTATION
}

BY

M. D. MIDDLETON, M.B., F.R.C.S., F.R.C.S.Ed. Surgical Registrar, Radcliffe Infirmary, Oxford

AND

\section{U. WEBSTER, M.B., F.R.C.S., F.R.C.S.Ed. Surgical Tutor}

From the Nuffield Department of Surgery, Oxford

" Amputation': one of the meanest, yet one of the greatest operations in surgery; mean, when resorted to where better may be done-great, as the only step to give comfort and prolong life." With these words Sir William Fergusson (quoted by Gordon-Taylor, 1955) gave his succinct views on amputation. Few surgeons would quarrel with this assessment. They would agree that having saved the patient's life by operating, or at least having made his life bearable, their main duty is to fashion a stump that can readily be fitted with a prosthesis. The sufferer can thus fend for himself, and may well be able to live a useful and comparatively active life. It is accepted that in peacetime the majority of amputees will be elderly, and that the commonest cause for amputation is advanced atherosclerosis affecting the lower extremity.

At the same time it must be added that the duty of the limb-fitter is to produce a satisfactory prosthesis to fit the stump, rather than the stump being fashioned to fit a standard prosthesis. As trends in surgery change and advance, so must limb-fitters alter their difficult art.

Our experience with the Gritti-Stokes amputation has convinced us that it is technically superior to the standard above-knee amputation, which, in the experience of many surgeons, is slow to heal and leaves an elderly patient with a short stump that is mechanically at a disadvantage both for wielding a prosthesis and for sitting in a chair. We have also found that artificial limbs for Gritti-Stokes amputees, as fitted at present, fall far short of the ideal. The difficulties stressed by the limb-fitting centres in this country (Gillis, 1961a) might well be overcome if a more satisfactory prosthesis could be designed. We believe that this is possible (Harris, 1962).

Our experience with a small series of cases is recorded below, and as a result we have been encouraged to continue with this operation.

\section{Historical}

In 1857 Rocco Gritti, a young surgeon at the Ospedale Maggiore in Milan, published an article giving a short history of amputations, and described a method of amputation through the knee, using the patella as an osteoplastic flap to provide an end-bearing stump. $\mathrm{He}$ described in detail how to perform the amputation, and ended with the plea that the operation was worthy of trial. He himself was too junior to perform it, and had only done so on a corpse. Neudorfer, in Vienna, appears to have been the first to attempt the operation shortly after the publication of Gritti's article. Numerous mod:fications have been described, mainly concerning the level of transection of the femur. Stokes's modification was said to be removal of the cartilage from the back of the patella: however, reference to Gritti's original article shows that he removed the cartilage with a bistoury and a saw. Stokes, however, did introduce an oval anterior flap in preference to the rectangular one described by Gritti.

The level of femoral transection is of prime importance in the ultimate success of the amputation, and has varied with the dictates of fashion, but all authorities are now agreed that it should not be too high, so that the patella can lie on a wide area of cancellous bons. Gritti recommended that the femur should be transected at the upper level of the epiphysial line, and this closely corresponds to the adductor tubercle, which is the landmark most commonly used. Little of importance has therefore been added to Gritti's original description.

The popularity of the operation has varied. It is not favoured by the main limb-fitting centres in this country (Gillis, 1961a), but is popular in Canada and in France (Chippaux et al., 1956 ; Harris, 1262).

\section{Technical Considerations}

After the osteoplastic flap of skin and patella is elevated the femur is transected at or near the level of the adductor tubercle. The patella is then anchored snugly over the femur by three strong catgut sutures, and is retained in place by the tightness of the attached tissues. If the femur is transected too far proximally the patella will tend to dislocate. This in turn is said to produce tender stumps and bony spurs, both of which have brought the amputation into disrepute with limbfitters.

After the femur is divided the poplit zal fossa is entered anteriorly and the great vessels can then be ligated. The sciatic nerve is severed with a knife at the same level, so that if neuromata - and subsequent painful phantom -develop, they will be accessible to percussion (Russell, 1949 ; Russell and Spalding, 1950).

The amputation is then completed by severing the muscle tendons rather than muscle masses. The popliteal fossa is obliterated with interrupted catgut sutures and the skin closed. A drain is left in situ for 48 hours, by which time the patient is allowed up on crutches and encouraged to move the stump as freely as possible. Skin sutures are retained for ten days.

\section{Results}

Of 25 Gritti-Stokes amputations performed over a period of two and a half years 24 were done for peripheral vascular disease; these patients included four who had diabetes. One amputation was done for a haemophilic blocd cyst (see Table).

\begin{tabular}{|c|c|c|c|c|c|c|c|}
\hline $\begin{array}{c}\text { Reason } \\
\text { for } \\
\text { Amputation }\end{array}$ & $\begin{array}{c}\text { No. } \\
\text { of } \\
\text { Cases }\end{array}$ & $\operatorname{Sex}$ & $\begin{array}{c}\text { Average } \\
\text { Age in } \\
\text { Years }\end{array}$ & $\begin{array}{l}\text { Opera- } \\
\text { tive } \\
\text { Deaths }\end{array}$ & $\begin{array}{c}\text { Primary } \\
\text { Hea'ing } \\
\text { of } \\
\text { Operative } \\
\text { Survivòrs }\end{array}$ & $\begin{array}{l}\text { Infected } \\
\text { Stumps } \\
\text { Among } \\
\text { Sur- } \\
\text { vivors }\end{array}$ & $\begin{array}{l}\text { Pros- } \\
\text { thesis }\end{array}$ \\
\hline $\begin{array}{l}\text { Athero- } \\
\text { sclerosis }\end{array}$ & 20\{ & $\begin{array}{lr}M & 16 \\
F & 4\end{array}$ & $\begin{array}{l}69 \\
72\end{array}$ & 1 & 16 & 3 & 10 \\
\hline $\begin{array}{l}\text { Diabetic } \\
\text { gangrene }\end{array}$ & 4\{ & $\begin{array}{ll}\mathrm{M} & 1 \\
\mathrm{~F} & 3\end{array}$ & $\begin{array}{l}61 \\
71\end{array}$ & 1 & 2 & 1 & 2 \\
\hline Haemophilia & 1 & M 1 & 35 & 0 & 0 & 1 & 1 \\
\hline
\end{tabular}

Two patients died before leaving hospital ; these can fairly be called operative deaths, thus giving a mortality rate of $8 \%$. There were also three late deaths, but all these patients were walking on either a pylon or prosthesis before they died. One patient who had left the area could not be traced for follow-up. 
Of 19 cases seen at a follow-up clinic 18 were at least six months post-operative.

The most frequent post-operative complication was infection of the stump, but this involved only 5 of the 23 patients who survived operation. Of this number, one was a haemophiliac who developed a small infected haematoma, and one bled into his stump after receiving anticoagulants for a near fatal pulmonary embolus, developing subsequent infection. Eighteen cases healed by first intention and were discharged from hospital within 16 days of operation.

Post-operative complications were: infected stumps in 5 , deep-vein thrombosis in 1, pulmonary embolus in 1 , and paralytic ileus in 1 .

All survivors stated that they had phantom limbs on occasion, but in only one was this troublesome and the patient was a poor witness. Of 18 long-term patients, 16 were pleased with the amputations and in 13 no fault could be found with the stump. Four, however, did have slight tenderness on pressure, and in one case, a haemophiliac, the patella was mobile. Seven cases had developed spur formation varying in size from $r$ to $2.5 \mathrm{~cm}$., but these could not be detected clinically and were not associated with tenderness. Similarly, patients with tender stumps did not in this series show radiological evidence of spur formation.

In some instances $x$-ray films of the stump showed that the patella had become displaced from the end of the femur, but this could not be detected clinically, and such stumps were firm on examination.

Six patients were not using prostheses, in one case because of a double amputation. Of the remaining five, three had incipient gangrene of the other leg, one was demented, and one had been operated on very recently.

A surprising finding was that seven patients could walk short distances without even one stick, but naturally preferred to carry one as added insurance.

The number of diabetic patients in the series, four, is too small to draw any definite conclusions, but the three who survived operation had little trouble with healing. Clinically their course was not significantly different from that of the remainder.

Although the majority of patients were satisfied with their stump, several complained that the prosthesis supplied was not satisfactory. Most were fitted with a standard limb for aboveknee amputation, modified for the extra length of the stump (Figs. 1 and 2). Only two patients were totally end-bearing, and these walked well. The others were mainly ischial-bearing because of the nature of the prosthesis.

\section{Discussion}

The Gritti-Stokes amputation is recommended by some contemporary surgeons (Chippaux et al., 1956; Jones, 1958, 1961 ; Martin, 1961 ; Harris, 1962) and strongly condemned by the limb- fitters and surgeons at Roehampton (Gillis, 1961a, $1961 \mathrm{~b})$. There is, however, surprisingly little information about the amputation in the literature.

In this small series the low mortality rate, $8 \%$, was satisfactory, taking into account that no patient was refused operation because of poor general condition. Gilchrist (1961) describes a mortality rate of $27.4 \%$ in 309 above-knee amputations performed in patients over 60 years of age.

From the surgical viewpoint there are several factors which are attractive in this operation. The high incidence of primary healing and early mobilization with subsequent short stay in hospital is of great benefit to these elderly patients. It is our impression that healing of the above-knee amputation is slow, probably associated with serous ooze from the large muscle mass which is severed; this does not occur in the GrittiStokes amputation, where tendons are cut rather than muscle mass. The limited degree of stump shrinkage and moulding which occurs allows a preliminary pylon to be fitted within a few weeks. The stump is long and powerful, as all muscle groups in the thigh are able to function. In addition, the end-bearing stump gives a better degree of proprioception than the above-knee amputation.

It is, however, mainly because of the experiences of the limb-fitters that this amputation has fallen into disrepute in Britain (Gillis, 1960).

It is said that the skin at the end of the stump is illfitted to withstand the trauma of end-bearing. This is not our experience, nor that in centres where the amputation is popular. Spurs undoubtedly do occur at the patellar-femoral junction, and the patella will s'ip if the femur is divided too high. In this series this was not associated with local effects. Those patients who had spurs did not have tender stumps. Those whose stumps were tender did not have spurs. Even if the patella did slip as shown on $x$-ray examination, the stump appeared clinically solid. The only instance where patellar mobility was obvious was in a patient suffering from



Figs. 1 and 2.-National Health Service prosthesis given to Gritti-Stokes amputecs. 
haemophilia, a condition in which it is likely that there is a connective-tissue defect.

The difficulty of manufacturing a suitable knee-joint is another factor militating against this amputation. However, if a through-knee amputation, which is at least 2 in. $(5 \mathrm{~cm}$.) lower, can be satisfactorily fitted, it must be possible to accommodate the shorter GrittiStokes.

The prosthesis supplied by the Ministry of Pensions is heavy and cumbersome, as is in fact a modified above-

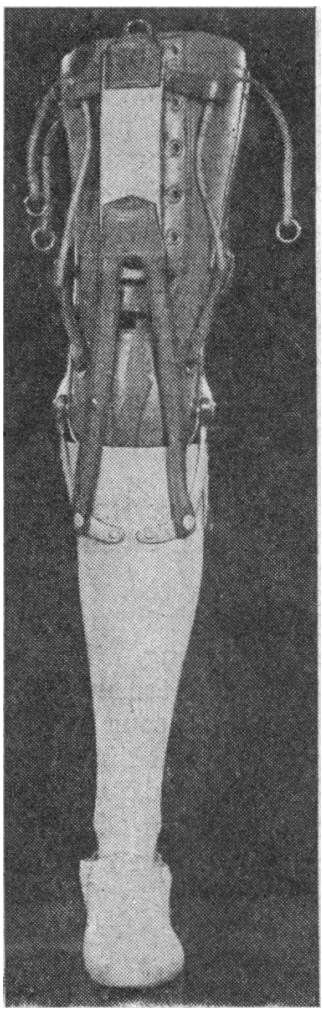

Fig. 3.-Prosthesis given to Gritti-Stokes amputees at the Sunnybrook Hospital, Toronto, Canada. knee prosthesis. There is thus no difference in weight, but the additional leverage of the long stump of the Gritti-Stokes amputation may be of advantage to the patient.

The prosthesis is partially ischial- and partially endbearing (Fig. 2), although some of our patients were fitted with a totally ischialbearing prosthesis. With this prosthesis they were able to walk, but with a locked knee ; we have never seen an elderly above-knee amputee walk with a free swinging knee, and such people always require a stick for support.

Harris (1962) fits all his Gritti-Stokes amputees with a different prosthesis (Fig. 3) which is totally end-bearing, and does not require a pelvic band, rotation being controlled by lacing on the thigh. An over-shoulder harness is also used. It would appear to be much superior to the British equivalent.

We have no experience of the through-knee amputation, but it would seem to have certain disadvantages, at least in theory. The anterior flap must be long and necessarily thin, to cover the bulbous femoral condyles, and the viability of this flap would appear to be precarious in the atherosclerotic patient. If, however, this is not the case it would seem to be the equal of a Gritti-Stokes amputation.

\section{Summary}

Twenty-five Gritti-Stokes amputations, the majority in the elderly, have been reviewed, and it is contended that this is a satisfactory operation. It is superior to the standard above-knee amputation in that rapid healing occurs in the majority of cases, mobilization is early, and the stay in hospital is relatively short.

The difficulties of fitting a satisfactory prosthesis have been examined, and it is suggested that a better limb could be made available; with this proviso, which is the major factor against this operation, we believe that a Gritti-Stokes is the best amputation that can be offered to the atherosclerotic patient who must lose a limb.

We thank Professor P. R. Allison and Mr. A. S. Till for permission to operate on and report these cases. We are also indebted to Dr. D. L. Harbinson, of the Limb Fitting Centre, Reading, for his co-operation.

\section{REFERENCES}

Chippaux, C., Scarbonchi, Petit (1956). Mém. Acad. Chir., 82,

Gilchrist, A. R. (1961). J. roy. Coll. Surg. Edinb., 6, 159.

Gillis, L. (1960). Ann. roy. Coll. Surg. Engl., 26, 24. (1961a). Brit. med. J., 2, 1355.

(1961b). Ibid., 2, 1786

Gordon-Taylor, G.'(1955). In Modern Operative Surgery, edited by G G Turner and L C. Rogers, 176 Cassell, London

Gritti, R. (1857). Annali Universali di Medicina (Milano), 161, 5

Harris, W. R. (1962). Sunnybrook Hospital, Toronto, Canada. Personal communication.

Jones, R. N. (1958). In Operative Surgery, edited by C. Rob and R. Smith, vol. 6, pt. XI, p. 28. Butterworths, London. (1961). Brit. med. J., 2, 1496.

Martin, P. (1961). Ibid., 2, 1495.

Russell, W. R. (1949). lbid. 1 . 1024.

and Spaiding, J. M. K. (1950). Ibid., 2, 68.

\section{SEA-SNAKE ANTIVENENE: SUCCESSFUL TRIAL}

BY

\section{H. A. REID, M.D., F.R.C.P.Ed., D.T.M.\&H.}

Director, Snake and Venom Research Institute, Consultant Physician, Penang General Hospital, Malaya

Sea-snakes are a common hazard to fishermen in Asian coastal waters (Reid and Lim, 1957). Unfortunately, land-snake antivenenes do not neutralize sea-snake venom. However, Carey and Wright (1960) showed that experimental antiserum made with venom of the common sea-snake Enhydria schistosa (Daudin) was also effective against venoms of other sea-snake species. A refined therapeutic sea-snake antivenene is now made at the Commonwealth Serum Laboratories, Melbourne, Australia, by immunizing horses with $E$. schistosa venom supplied from the Snake and Venom Research Institute, Penang. Shortly after this new antivenene was received in Penang, it was used to treat two victims admitted with severe poisoning.

\section{Case 1}

A 16-year-old Malay fisherman trod on a sea-snake as he stepped out of his boat and was bitten on the left foot at 11 a.m. on December 21, 1961. The sea-snake species was not recognized. No first-aid measures were applied. $\mathrm{He}$ walked home and at 11.30 a.m. noticed pain in his throat and limbs, and felt thirsty. He cycled to a police station and was eventually transferred to Penang General Hospital, arriving at 2.30 p.m. He already had serious poisoning, with pronounced muscle-movement pains on flexing limbs, neck, and trunk. Facial and jaw movements were also very painful. Muscles were tender on compression. Tendon reflexes were brisk and neurological examination was negative. No paresis was evident (although the patient was reluctant to move on account of the pain it caused). Multiple sea-snake-bite marks were present on the dorsum of the left foot. Blood-pressure (B.P.) was $150 / 100$, heart rate 90. The remaining physical examination revealed nothing of note.

By 3.30 p.m. muscle-movement pains were more severe ; B.P. 150/110. There was slight ptosis and he was unable to turn either eye outwards to the full extent. The white-cell count was $18,100 /$ c.mm., and urine-the first passed since the bite-showed the typical brown colour of myoglobinuria (later shown to be spectroscopically positive). It was now evident that he had severe poisoning likely to be fatal by comparison with previous cases (Reid, 1961a, 1961b). There was no reaction to a test subcutaneous injection of $0.5 \mathrm{ml}$. of sea-snake antivenene given at 4.10 p.m. An 